$12-6-2018$

\title{
The Lay Folks' Catechism, Alliterative Verse, and Cursus
}

Ian Cornelius

Loyola University Chicago, icornelius@luc.edu

Follow this and additional works at: https://ecommons.luc.edu/english_facpubs

Part of the English Language and Literature Commons, and the Medieval Studies Commons

Author Manuscript

This is a pre-publication author manuscript of the final, published article.

\section{Recommended Citation}

Cornelius, Ian. The Lay Folks' Catechism, Alliterative Verse, and Cursus. The Review of English Studies, , : 23, 2018. Retrieved from Loyola eCommons, English: Faculty Publications and Other Works,

http://dx.doi.org/10.1093/res/hgy107

This Article is brought to you for free and open access by the Faculty Publications and Other Works by Department at Loyola eCommons. It has been accepted for inclusion in English: Faculty Publications and Other Works by an authorized administrator of Loyola eCommons. For more information, please contact ecommons@luc.edu. c) (i) $(9$

This work is licensed under a Creative Commons Attribution-Noncommercial-No Derivative Works 3.0 License. (c) The Author 2018 


\section{The Lay Folks' Catechism, alliterative verse, and cursus}

abstract The Lay Folks' Catechism is an English rendering of injunctions issued in 1357 by John Thoresby, Archbishop of York, setting forth the elements of Christian belief. Ever since W. W. Skeat's treatments, the Catechism has been placed in the general orbit of alliterative verse, yet closer identifications have proved elusive. The text is now recorded in both The Index of Middle English Verse and The Index of Middle English Prose; the principal stylistic study proposes that John Gaytryge, the author of the English text, may have been influenced by the system of Latin prose rhythm known as cursus. Renewed treatment must begin by establishing an accurate and authoritative text. Collation of the two best copies, York, Borthwick Institute, MS Abp Reg 11 and Oxford, Bodleian Library, MS Don.c.13, confirms the general authority of the York copy. Recent studies of alliterative metre allow Gaytryge's composition to be distinguished with confidence from that English verse form. Affiliations to Latin cursus are more difficult to assess, but doubtful: more likely influences are the Latin of the Creed, Pater noster, and other pastoralia, and the plain style that preachers were instructed to adopt in preaching to the laity. The form of the Catechism may have been a deliberate innovation: a new plain style in the vernacular, aiming to embody the priorities of pastoral instruction.

In Old English and Middle English Poetry, Derek Pearsall made a schematic distinction between a 'nucleus' of Middle English alliterative verse and a 'penumbra shading off on every side into other forms of writing'. ${ }^{1}$ In the nucleus, Pearsall located a group of poems, mostly romances, composed in unrhymed long lines: Winner and Waster, The Siege of Jerusalem, several poems on Alexander, the alliterative Morte Arthure, Sir Gawain and the Green Knight, Cleanness, Patience, St. Erkenwald, and a few others. Very near this nucleus are unrhymed poems of plainer style and more southerly provenance: Piers Plowman and its epigones. In the penumbra one may place rhymed stanzaic poems bearing alliteration, alliterative rhythm, or both; metrically irregular verse such as the The Simony; the ambiguous composition known as The Lay Folks' Catechism or Gaytryge's Sermon; and the rhythmical alliterating prose of Richard Rolle and A Talkyng of pe Loue of God. Contemporary with Pearsall's treatment, several other scholars were 
engaged in pulling the penumbral works out of the shadows. In different ways, N. F. Blake, Elizabeth Salter, and David A. Lawton, among others, inquired whether certain texts previously relegated to the edges of the alliterative tradition might help explain the sudden emergence of the unrhymed alliterative long line in surviving records around the middle of the fourteenth century. ${ }^{2}$ The question took several forms. In one manifestation, the aim was to uncover the formal ingredients and genetic antecedents of the unrhymed alliterative line. In another, the aim was to explore the particular circumstances of composition and circulation of the surviving alliterative poems. Perhaps most profoundly, this research sought to re-conceive the fourteenth-century alliterative tradition in terms of 'modes and affiliations' that would cut across any divide between nucleus and penumbra.

That reconceptualization had sharply differentiated fortunes in its two principal areas of implementation. In manuscript studies, Salter's catholic approach to 'modes and affiliations' of literary culture remains exceptionally productive. It has been less productive in formalist study of alliterative verse, where the most important subsequent contributions have derived instead from research on metre, and this research has tended to re-inscribe the old division between nucleus and penumbra. Metrists have concentrated their attention on a group of about a dozen poems, selected for their considerable uniformity in language and style. This has been a research expedient, intended to reduce the number of variables in play, and it has enabled researchers to identify prosodic regularities that have transformed modern understanding of alliterative verse. ${ }^{3}$ Initial reports from this research area were essentially synchronic, concerned to describe the prosodic structure of the fourteenth-century poems under study, yet questions of diachrony became pressing as new findings accumulated: one wanted to know where the verse structure 
came from and how it developed. Several reconstructions are now available; each derives the fourteenth-century alliterative metre from the metre of Old English poetry, thus positing a continuous practice of versification in a continuously evolving form, stretching from one end of the Middle Ages to the other. ${ }^{4}$ Significantly, these diachronic reconstructions do not construe the rhythmical prose of Ælfric as part of the developmental sequence between the metre of Beowulf and the metre of the fourteenth-century 'alliterative revival'. Nor do they find a place for the Middle English texts that Blake, Salter, and Lawton sought to place in the lineage of alliterative verse. Though many issues remain unresolved, recent studies generally agree that the fourteenthcentury alliterative metre was a traditional form with a long prehistory; its formal antecedents should not be sought in compositions contemporary with the 'revival'. The result is that The Lay Folks' Catechism and other texts adduced in the 1960s and 70s by scholars grappling with the origins of the 'alliterative revival' remain without a clear place in literary history.

In a 1978 article, Salter proposed that The Lay Folks' Catechism 'illustrates the probable nature of some of the old raw materials from which Langland would have been able to refine his good verse line' ${ }^{5}$ In an article published the following year, Lawton described the Catechism as an 'antecedent' and 'very near relation ... of M.E. unrhymed alliterative poetry.' ${ }^{6}$ These formulations are not easily reconciled with current understandings of alliterative metre and its historical development. Yet an attempt to give the Catechism a new place in literary history opens onto questions central to Salter's research: the field of possibilities for stylistic innovation in English in the mid fourteenth century, and the historical study of style in contexts of multilingual literary production. 


\section{The Text and its Genesis}

The title Lay Folks' Catechism is modern but descriptive. ${ }^{7}$ The text is a summary exposition of Christian belief, a syllabus outlining the minimum that a priest ought to know about his religion and teach to his parishoners, as established in the Fourth Lateran Council of 1215-16 and in subsequent church legislation. ${ }^{8}$ It consists in the fourteen articles of the Creed, the ten commandments, seven sacraments, seven deeds of mercy, seven virtues, and seven deadly sins. In its opening and closing the Catechism identifies itself as the initiative of an unnamed archbishop, undertaken through the counsel of his clergy. This internal description is evidently accurate. The earliest copy is in the register of John Thoresby, archbishop of York from 1353 to 1373. ${ }^{9}$ This copy was probably made in 1357 , for it is followed in the register by a Latin memorandum issued by Thoresby to his subordinate clergy in that year and likewise setting out a catechetical syllabus for instruction of the laity.

The Latin and English texts do not correspond precisely: the English text differs from the Latin in arrangement of materials and by addition of the spiritual works of mercy. Moreover, the English text replaces the compressed and formulaic language of an intra-institutional memorandum with language more suitable to the teaching stipulated by that memorandum. Henry Edward Nolloth remarked that the Catechism 'is really a very wide expansion of the original text' ${ }^{10}$ Gaytryge's rendering of the seventh article of the faith, concerning resurrection and judgement, supplies an example. I quote the Latin injunction and Gaytryge's rendering: ${ }^{11}$ 
Septimus est credere carnis resurrectionem et vitam eternam, videlicet, quod omnes in die iudicii sumus in carne et anima veraciter surrecturi, et tunc erit eterna gloria electorum et dampnacio perpetua reproborum.

The seuent article that vs awe to trow

Is vprisynge of flesh and lyfe withouten end

For when that dede has sondred oure bodies and oure saules

For a certayne tyme als oure kynde askes

Vnto when that god sal deme the quike and the dede

Than oure saules sal turne ogayn til oure bodies

And we thas ilke and naneothir than we er now

Sothefastly sal rise vp in bodi and in saule

That neuermare sal sondire fra that tyme forthe

Bot samen if we wele do whiles we er here

Wend with god to that blis that euermare lastes

And als if we iuel do til endeles payne

Gaytryge has filled out the meaning of the original, pausing over the fact of death before turning to the main point of resurrection and judgement. Expansions explain the dual nature and reality of the resurrection - a fine point that the Latin was content to render by an adverbial formula, 'in carne et anima veraciter'. Gaytryge emphasizes that body and soul divide at death, that they will be rejoined at the resurrection, and that we shall be then as we are now, except that body and soul will be inseparable thereafter. To render these points and their significance, he turned the three verbs of the Latin original (est credere ... sumus surrecturi ... erit) into fourteen. Such 
amplification is characteristic of Middle English translations from Latin: Traugott Lawler demonstrates similar multiplications of clauses in passages of Piers Plowman translated from known Latin sources. ${ }^{12}$ Like other translators of his time, Gaytryge strove to do something more than render the sense of the original text: he strove also to explain and adapt the Latin text to a new public and new circumstances of reception. In Lawton's words, 'the translation gave effect to the intent of the Latin instruction'. ${ }^{13}$

A separate collection of Thoresby's correspondence preserves a copy of the letter commissioning the English translation. ${ }^{14}$ The letter states that the decision to have this translation made was taken by the clergy in convocation: 'Ulterius, in dicto consilio condutum fuerat quod premissa ... scriberentur in wlgari, et sic per dictas diocesim et provinciam mitterentur' ('it was furthermore agreed in the said council that the above ... should be written in the vernacular and sent throughout the said diocese and province'). ${ }^{15}$ The addressee of the letter and recipient of the translation commission is identifiable as a J.[ohn] de Gaitrik' of St Mary's Abbey, York (OSB), an identification that agrees with scribal ascriptions in four later manuscripts. ${ }^{16}$ The circumstances of the genesis of this text are therefore recoverable with exceptional confidence and detail. The archbishop flatters Gaytryge's eloquence ('vos, quem deus scienciarum dominus floribus dotavit eloquencie'), but instructs him to strive more for speed and clarity than for ornament: ${ }^{17}$

premissa vobis duximus destinanda, ex corde rogantes, quatinus predicta cedula debite recensita, contenta in eadem grosso modo cum celeritate possibili transferatis, plus querentes in translacione ipsa, cum sit ad laicorum informacionem, ut dicitur, ordinata, intellectum patulum quam ornatum. 
(We decided that we should send the above to you, asking from our heart that, having duly reviewed this schedule, you translate its contents in summary form with all possible speed, striving more for a clear meaning than for an ornamented one, seeing as the translation is (as one says) intended for the instruction of the laity.)

Thoresby directed Gaytryge to adopt a plain style suited to the task of pastoral instruction. This charge could license a variety of stylistic decisions, yet it points at least to the existence of a choice: it presupposes that other, more ornate styles were available. One of the aims of the present essay is to recover the meaning of Gaytryge's choice. Investigation of this question must first establish an accurate and authoritative text of the Catechism.

\section{The Manuscript Record}

The Catechism is transmitted in whole or part in twenty-six manuscripts. ${ }^{18}$ Three versions of the text have appeared in print. A copy written by the fifteenth-century Yorkshire gentleman Robert Thornton was published by EETS in $1867 .{ }^{19}$ EETS subsequently published the Thoresby register copy en face with the text of London, Lambeth Palace Library, MS $408 .{ }^{20}$ The interest of the Thornton and Lambeth texts is as witnesses to reception history. ${ }^{21}$ The Thoresby register has an excellent external claim to authority: it is an official document conceivably made at Thoresby's order from Gaytryge's holograph or presentation copy. Anne Hudson has identified the Thoresby register copy as one of twelve that transmit the Catechism complete or nearly complete, in what appears to be its original form; Hudson designates these twelve manuscripts as her 'group 1'. A.I. Doyle identified the scribe of the Thoresby register copy of the Catechism and Latin injunction as the Thomas de Aldefeld, who contributed several other entries to the register 
around the same time. ${ }^{22}$ Doyle also observed that the Catechism and Latin injunction fill an independent quaternion: they could have been circulated for use as an official exemplar prior to binding in the register. If the Thoresby register could be shown to stand at the head of the manuscript tradition, all other copies would be codices eliminandi, in the sense that their texts could differ from the register only by the accumulation of additional layers of copying error.

Hudson found reason to reject this hypothesis. In at least two instances, the Thoresby register gives a reading evidently inferior to that of the majority of group 1 copies. ${ }^{23}$ The best of these other group 1 copies - and the only other copy to preserve the Catechism 'essentially as it appears in the Thoresby register' - is Oxford, Bodleian Library, MS Don.c. $13 .{ }^{24}$ Hudson accordingly suggested that 'a future editor might be well advised to consider using [the Bodleian manuscript] as base text'. ${ }^{25}$ Following Hudson's lead, I have sought to expand the evidentiary basis for adjudication between these two manuscripts. My collation of the Thoresby register (henceforth sigil T) and Bodleian Library, MS Don.c.13 (henceforth sigil Z) reveals about 235 substantive variants, or an average of about two variants per five lines. The Latin source text provides almost no help in adjudicating variant readings, for Gaytryge's translation is free and expansive. Considerations of form are likewise unhelpful, for the form of the text appears too loose - and is not well enough understood - to adjudicate between numerous small variants of the type when that $] \mathrm{T}$; when $\mathrm{Z}$. Yet there remain a handful of variants assignable on the basis of sense, syntax, and conformity to recognized patterns of scribal error. These assignable variants confirm that $\mathrm{T}$ and $\mathrm{Z}$ are good independent witnesses to their shared archetype: each may be used to correct small errors in the other. 
Since I will employ the EETS edition of $\mathrm{T}$ as reference text in analysis of $\mathrm{T} / \mathrm{Z}$ variants, $\mathrm{I}$ first record transcription errors and unannounced editorial interventions in that edition. This list and the next incorporate and extend the corrigenda printed by Lawton. ${ }^{26}$ I record the printed reading followed after the bracket by the reading of the manuscript:

12 angel] angels. 16 fadyr] fadirs. 17 innocency] innocentz. 38 defaitor] defaute. 156 hegher] hegh. 165 deserves] serues. 197 to (1)] om. 250 gere] gert. 260 is] is that. 268 the] all the. 315 synnes] synned. 335 lessyne] lessynge. 358 for] for to. 370 is] om. 371 us] om. 393 ne (2)] na. $394 \&$ ] or. 401 al] til. 403 our] ouer. 408 all] til. 410 al] til. 424 thew] thew is. 436 saffely] stiffely. 564 his] om.

In several cases the editors simply misread the manuscript. At line 156 they misconstrue a bar through final $h$ as an $e r$ abbreviation; this reading and the silent emendation at 16 may be motivated by theology: God is higher than the angels; only a single forefather enjoyed the state of prelapsarian innocence. ( $\mathrm{Z}$ reads as $\mathrm{T}$ in both cases; the reading hegher is unwarranted in context but fadir may be correct at line 16.) Like fadyr at 16, the printed readings at lines 38, $165,315,370$, and 371 are silent emendations. Emendation at 165 is not justified (see MED, s.v. 'serven, $v .^{2}$ '). Line 370 is debatable, but the text of $\mathrm{T}$ is indeed corrupt at 38,315 , and 371 . At 315 and 371 the emendation is obvious and supported by Z. Z likewise supplies the correct reading at line 38 , for which see below.

In addition to these substantive errors and unannounced emendations, the EETS editors several times misrepresent the segmentation of their text. Though written in continuous format as prose, the Thoresby register text bears careful and regular punctuation, marking off verse-like 
segments. While imposing modern punctuation, the EETS editors took Aldefeld's punctuation as a cue to lineate their text as verse, an editorial decision supported by other early northern copies, as I will explain in the next section. Yet the printed lineation errs in the following cases:

4 and in erthe belongs with the previous segment. 67-68 as three segments divided after sugettes and shrift. 263 as two segments divided after thought. 340 as two segments divided after minister. 506-7 as three segments divided after covatise and yernyng.

By their silent re-division of the text, Simmons and Nolloth evidently aimed to avoid exceptionally long or short lines. This ambition was not misplaced, but the strategy employed has the effect of smoothing over and obscuring transmission error: comparison with $\mathrm{Z}$ shows that, in at least one case, an unusually short segment in $\mathrm{T}$ is short because Aldefeld omitted words that stood in his exemplar.

These corrigenda noted, we may proceed to analysis of $T / Z$ variants. In the lists that follow I print the reading of $\mathrm{T}$ followed after the bracket by $\mathrm{Z}$; line references are again to the 1901 EETS edition. I take $\mathrm{Z}$ to be superior in the following cases:

38 defaute] defaute fallis. $68 \mathrm{kun}]$ knawe \& kunne (T read and kun prior to correction). 127 That] Is pat. 135 and (1)] to. 136 many] tholed many. After 184 pat we sai nozt in his name bot it be sothfast. 148 Als] sa. 192 \&] or. 194 to (2)] ne. 254 Of] pof. 310 stedefast] sothfast. 315 synnes] synned. 371 greued] greued vs. 390 cristen] cristenly (cf. 204). 396 godedis] gode dedis. 485 wilnesse] wilnes. $488 \&$ mony] athis \&. 537 thare are] whare pat. 570 hele] hele \& help ( $c f .530)$. 
At lines 38, 68, and 135-36, Z supplies readings superior to both $\mathrm{T}$ and the efforts of the EETS editors to repair T: in each case, comparison with $\mathrm{Z}$ shows that $\mathrm{T}$ has dropped a word. At line 68, where the EETS editors re-lineated their text, the canceled word and, which is ungrammatical in context, indicates that Aldefeld probably omitted, by oversight, the first element of the doublet preserved at this location in $\mathrm{Z}$ and transmitted by both copies elsewhere in the text (see lines 31 , 563). The variants at lines 254 and 488 are discussed by Hudson. T gives muddled or broken syntax in the first of these lines and in lines $127,135,148$, and 537, usually through miswriting of a small grammatical word, once by omission of a copula. Miswriting at line 135 could have been induced by anticipation of following copy. In several other cases, confusion of small grammatical words damages sense. At line 192, Gaytryge relates the obligations of clerics and laity to hear or (T: and) to perform the service on holidays 'aftir thair state is'; the statement requires Z's disjunctive or. Like line 68, the variants at line 194 and 570 involve doublet constructions (at 194, to tent ne tary with the world), a frequent feature of Gaytryge's language. At line 310 Gaytryge lists the qualities of penance; the sense seems to require sothfast; T's stedefast may have been induced by the appearance of this word earlier in the text. Finally, the line present in $\mathrm{Z}$ but not $\mathrm{T}$ is best assessed in context, where Gaytryge's topic is the second commandment. I quote the text of MS Don.c. 13 , f. $163^{\mathrm{v}}$, col. a, corresponding to lines $182-86$ in the printed text of the Thoresby's register, and render the scribe's punctus elevati as colons:

Pe secounde comaundement : biddis not take In idilship ne in vayn : pe name of oure god sa pat we trowe not of his name : bot it be stedfast pat we sai nozt in his name : bot it be sothfast 
pat we swere not his name : bot bihouely

pat we neuen not his name : bot worshipfully

Omission of the fourth line above can hardly be claimed to damage the sense, but the repetitiousness on display here is typical of the Catechism and would have facilitated accidental omissions: similarities of lines at end (stedfast ... sothfast) and beginning (bat we ... pat we) supply ideal conditions for eye-skip. The line was probably present in Aldefeld's exemplar. With the exception of the Catechism, Aldefeld's contributions to MS Abp Reg 11 are all of Latin documents, which would constitute his principal field of writing as a notary. If miswritings in his copy of the Catechism require explanation, they could perhaps be attributed to the language of the text.

Conversely, the text of $\mathrm{T}$ is superior in at least the following cases. In some cases I print explanations of the $\mathrm{Z}$ variant in parentheses:

19 Noght] Bot not (anticipation of the following line). $32 \mathrm{com}$ ] to com. 35 loue] loues. 35 serue] serues. 115 Bot] bath (semantic attraction to the subsequent word, 'samen'). 129 before] withouten (attraction to previous copy; see 124-5). 165 whethir sum] wheper sa. 170 that er] om. (compression; compare phrasing of 172). 179 Alle (1)] And alle (attraction to surrounding copy). 201 And] pat. 207 fifte] fifte poynt. 219 of] bat. 247 withhaldand] withalden. $267 \mathrm{com}$ ] to com. 351 god sal reherce] sal be reherced. 425 wathis] athis. 446 lawe] boke (substitution of an easier reading; $c f$. the alliterative formula 'as the book telles'). 452 And] bat (attraction to surrounding copy; compare 454). 541 stamerynge] standing. 547 aynlepi $(1,2)]$ sengyl. 
At lines 32, 35, 201, 219, 247, and $267 \mathrm{Z}$ loses track of continuing syntactic constructions. Z readings are likewise deficient in syntax at lines $19,115,129,351-2$, and 452 . It is difficult to see how the $\mathrm{Z}$ reading at 351 arose, but it must be derivative because it leaves the verb wit in the following line without a subject. At 170,179, and 207, Z gives acceptable sense but departs from patterns of expression established elsewhere in the text: line 207 introduces the fifth commandment; whereas other elements of belief are termed 'points', the commandments are either named as such (e.g., 'The sext commandement') or simply numbered (e.g. 'The ferthe'). At line 541 stamerynge is presumably the original reading, for it is not likely to have arisen from Z's standing; the Z reading has the appearance of variation towards prosaic expression. The most interesting of the variants is probably the one in line 425 , in which prudence is named the virtue 'That wisses vs to be war with wathes of the world'. With wathes means 'against dangers'. The Z reading may have originated as haplography ( $w^{t}$ wath- $>w^{t}$ ath-) facilitated by a word that the scribe failed to recognize. The variants in lines 165, 446, and 547 likewise suggest a tendency to simplify vocabulary in $\mathrm{Z}$ or its textual lineage. The spelling aynlepi (547) is unusual but authentic. $^{27}$

A proper assessment of $\mathrm{T}$ and $\mathrm{Z}$ - their relation to one another and to their shared archetype, and their relative claims to represent Gaytryge's work - must await Pamela Greig's comprehensive study of the surviving textual record. ${ }^{28}$ The analysis I have presented here is a stop-gap measure. Simpler mechanical errors recorded in the previous paragraphs would be readily correctable, and are best ignored in assessing the relation between copies. (T's miswriting at $315,371,390,396$, and 485 certainly fall in that category, as does the reading of $\mathrm{Z}$ at 247 .) Yet confusion of syntax at line 254 in $\mathrm{T}$ and the unoriginal variants at lines 351-2, 425, and 541 
in $\mathrm{Z}$ would be harder to put right. These variants and the line omitted by $\mathrm{T}$ suggest that the two copies are independent: each preserves readings presumptively original at points where the other errs.

Collations also reaffirm the authority of the Thoresby register copy. $\mathrm{T}$ is fallible, as Hudson recognized, yet T's evident errors are more often mechanical in character, whereas Z's errors suggest a weaker grasp on the language of the text, as evidenced by confusion of syntax and simplification of vocabulary. Indeed, the quality of the erroneous $\mathrm{Z}$ readings would seem to confirm what one may infer from external evidence. As Hudson's research shows, MS Don.c.13 was made $c .1400$ to hold an English Wycliffite sermon cycle; though expurgated, the sermons remain heretical, which suggests that the book probably originated outside the purview of church administration. If the Catechism was initially published to clergy of the York archdiocese through networks developed for the transmission of church legislation, as Vincent Gillespie has suggested, ${ }^{29}$ then Z's Wycliffite sermons and belated date place it outside that initial publication network. Since the preliminary evidence of textual criticism is consistent with inferences based on codicology, I shall retain the Thoresby register as the basis for study of this text, corrected to adopt the superior $\mathrm{Z}$ readings identified above. Line references are to the 1901 EETS edition of this text, but I quote from the digital facsimile of the manuscript, published on-line by the Borthwick Institute.

\section{Manuscript Format}

Manuscript punctuation and lineation have already commanded notice in passing. These 'accidentals' must now be examined directly, for scribal presentation formats supply vital, 
though conflicting, data on the intentional form of the Catechism. Though written without line breaks, the Thoresby register text is punctuated to mark off verse-like segments that correspond to line breaks in several other northern copies of the text. Five copies, all belonging to Hudson's group 1, are lineated throughout, while another two group 1 copies adopt a lineated format after the beginning. ${ }^{30}$ All but one of the lineated copies are written in Yorkshire language, while the only group 1 copy in Yorkshire language not lineated as verse is the Thoresby register itself. (Another prose copy was written in Yorkshire, but from an exemplar showing prior transmission further south: this is Lincoln Cathedral, MS 91, the copy written by Robert Thornton.) On this evidence, it seems that the Catechism may have circulated first in a format lineated as verse. Thomas de Aldefeld may have compressed a lineated text into continuous format to fit the relatively narrow purpose of the episcopal register, where texts are entered for reference consultation, not regular use.

Yet there are contrary indications, evidence that lineated format was belated, adopted by scribes who copied from exemplars in which their text was written without line breaks. The scribes of Cambridge, Trinity College, MS B.10.12 and London, British Library, MS Additional 25006 began writing in continuous format, then switched to lineated format for the remainder of the text. Bodleian Library, MS Don.c.13 is lineated throughout, but irregularities in lineation show that line structure was sometimes a matter of doubt. Such irregularities would be explained if, somewhere in the line of transmission behind Z, an exemplar was written without line breaks. Like the question of textual relations, this one requires a comprehensive study.

What is clear in the presentation of Z, Hudson's preferred manuscript, is the scribe's intention to present the Catechism as English verse in a long-line form. The long lines of the 
Catechism overrun the text box ruled for the preceding prose sermons; on occasion the scribe runs the text into the margin or onto a neighboring line. Most significantly, the scribe employed punctus elevati to mark off half-line units. Whether written continuously or lineated, early copies of Middle English alliterative verse typically have some mark of punctuation at the caesura. The septenary lines of the South English Legendary receive the same treatment. ${ }^{31}$ Thomas de Aldefeld punctuated only lines, not half-lines, but the Z-scribe's punctuation is true to the syntax of the Catechism, which generally divides into half-line units. Moreover, the Z-scribe was consistent, omitting punctuation in less than 2 per cent of lines. ${ }^{32}$ There are some aberrations, where punctuation is keyed to list structure rather than its metrical structure: for example, "be ferth is : ouer hastily to ete or to drynke' (500), where the metrical division is after hastily. These deviations excepted, the punctuation is generally metrical in character; as such, it encourages a reading of the Catechism as verse, even if identification of its verse form has proved elusive.

\section{Style: The History of the Question}

The stylistic peculiarities of the Catechism were first noticed in modern study in the 1860s. In correspondence with George Perry, Walter Skeat affirmed that, whatever the manner of presentation of the text in later manuscripts, it was 'originally in verse' ${ }^{33}$ As illustration, Skeat quoted a passage from Cambridge, Trinity College, MS B.10.12, f. $58^{\mathrm{v}}$, where the text is lineated as verse. The passage presents the sixth point of belief regarding Christ's manhood. ${ }^{34}$ Skeat proposed to scan it as follows:

Pe séxte póynt is · pát we sall trówe pat pe foúrtyde dáy · áfter pat he ráse, 
thurgh stréngh of hemsélfe · he stéghed vntil héuen,

whare oure kýnde is nów - in his blýssed pérson,

noght ánely éuen · no méte til his aúngels,

bot héghe corounde kýnge · abóuen ${ }^{35}$ all aúngels.

The mid-line pointing is Skeat's addition (the Trinity manuscript has no regular punctuation) but well taken, for the passage divides neatly into half-lines, and the half-lines are generally interpretable as having two lifts. Skeat judged line 3 'nearly perfect'; of the whole six-line passage, he remarked, 'It is clear that we have here the regular alliterative verse, perfect as regards accent, imperfect as regards alliteration' ${ }^{36}$ The lines are rather light: grammatical words must be promoted to supply lifts in the first half-line of lines 4 (now) and 5 (anely) and in the second half-line of lines 1 (bat), 2 (after), and 6 (abouen). Yet, with one exception, b-verses in the passage are metrical, having at least four positions and a long dip either between the two lifts (e.g., $5 b$, 'no mete til his aungels' [xSxxxSx]) or before the first lift (4b, 'in his blyssed person' $[\mathrm{xxSxSx]})$. The exception is the second b-verse: 'after pat he rase' presumably scans $\mathrm{SxxxS}$ (rase, third-person singular preterit of the strong verb, is monosyllabic), and thus falls short of the expected count of metrical positions in unrhymed fourteenth-century alliterative verse.

The terms of analysis employed in the previous paragraph are those of recent metrical study and would not have been available to Skeat. Yet Skeat, too, had doubts. In his 'Essay on Alliterative Poetry', he remained adamant that the Catechism ought to be printed as verse, but he now placed it in a tradition of rhythmical prose.${ }^{37}$ Just as Milton had influenced subsequent English prose, Skeat reasoned, so alliterative verse probably left its mark in prose of the Old and Middle English periods. Though Skeat continued to describe the Catechism as 'the very kind of 
metre into which the old Piers Plowman metre would naturally degenerate', he counterbalanced that language of degeneration with a positive formal designation: 'Semi-alliterative Rhythmical Prose ${ }^{9}{ }^{38}$ In a note on the rhythm of Ælfric's homily De octo vitiis, Skeat offered the prevarication 'semi-alliterative verse or rhythmical prose', again citing the Catechism as a characteristic instance of the style. ${ }^{39}$

Gaytryge's text has remained where Skeat placed it, in a grey area between verse and prose. It is recorded in the Index of Middle English Verse and its successors (IMEV 406, NIMEV 406, DIMEV 671), but also in the Index of Middle English Prose. ${ }^{40}$ Salter stated that 'the characteristic pattern is of lines with a predominantly four-beat structure, very variably emphasised by alliteration' and quoted some lines 'loosely reminiscent of lines in Piers Plowman ${ }^{41}$ David Lawton's 1979 article is the sole subsequent stylistic study. In that essay, Lawton sought to account for both Gaytryge's intermittent resemblances to alliterative verse and his considerable distance from it. Whereas Skeat had described the Catechism as the kind of verse that Piers Plowman might have degenerated into, Lawton ventured that the Catechism may have been 'an antecedent - chronologically, a very near relation - of M.E. unrhymed alliterative poetry' ${ }^{42}$ Lawton further sought to show that Latin cursus may have been a model for the rhythmical cadences that the Catechism shares with alliterative verse. In arguing for the importance of Gaytryge's Catechism in the historical development of literary English, Skeat, Salter, and Lawton recognized that Gaytryge did not write in alliterative metre: rather, they perceived and sought to explain resemblances to that metre. Recent metrical work allows the differences to be specified. 


\section{Prosodic Analysis}

Gaytryge's half-lines are often light. Above we noticed the anomaly of the half-line 'aftir that he ras' (152b). More egregious examples include 'for to gyfe it' (291b) and 'for to kun tham' (565b) - two half-lines that conceivably scan xxSxS (with infinitive inflections supplying a monosyllabic dip between lifts), but for which a one-lift, three-position scansion is a distinct possibility: xxSx. Both scansions are unmetrical in the Gawain-metre; the second would be unmetrical in the metre of Lawman's Brut, too, if recent work on that poem can be trusted. Scansion is hazardous in this context, for scansion depends on protocols rooted in verse traditions, and it is doubtful whether one justifiably invokes the protocols of alliterative scansion to parse Gaytryge's composition. Fortunately, the peculiarity of the Catechism may be captured by other means, also illustrated by the two half-lines $291 \mathrm{~b}$ and $565 \mathrm{~b}$. Fourteenth-century alliterative poets avoided constructions that would place monosyllabic pronouns and prepositions at line end. ${ }^{43}$ Langland was more permissive than others in this respect, but even he did not write stretches like the following, from the end of the Catechism (in which the half-line punctuation is my addition):

This er the sex thinges - that I haue spoken of

That the lawe of halikirke $\cdot$ lies mast in

That ye er al halden · to knawe \& to kun

If ye sal knawe god almighten · and cum vn to blisse

And for to gife yhou better wille for to kun tham

Oure fadir the ercebisshop - grauntes of his grace

Fourti daies of perdoun $\cdot$ til al that kunnes tham 
Or dos thaire gode diligence $\cdot$ for to kun tham

$\&$ ratifies als so $\cdot$ that othir men gifes

So mikel couaites he $\cdot$ the hele of yhoure saules (f. $297^{\mathrm{v}}$; 11. 561-70 in the EETS edition)

It would be easy to bring deviant lines in this passage into closer agreement with the usage of alliterative poets. For 567b, 'til al that kunnes tham', one may read 'til al that tham kunnes' [xSxxSx]: SOV syntax removes the offending monosyllabic pronoun from terminal position and yields a regular prosodic contour. Similarly, one may read 'tham for to kun' [SxxSx] rather than 'for to kun tham' (565b, 568b). With these syntactic inversions, the half-lines would not be out of place in an alliterative poem. Line 561 could be accommodated in much the same way: 'that I haue of spoken' [xxxSSx] (compare Sir Gawain and the Green Knight 1242b, 'pat $3 e$ of speken'). Alternatively, Gaytryge could have written 'that I to-for nempned' [xSxxSx]. There are many similar instances, similarly correctable, elsewhere in the Catechism.

I am not, however, suggesting emendations. One could imagine that Gaytryge wrote a traditional alliterative poem, rejected by Thoresby as unsuitable to his purposes, and suppose further that Gaytryge or someone else subsequently redacted his original composition prior to publication, canceling metrical filler-words and replacing poetic inversions with prose syntax. In support of this hypothesis, one could note that the verse character of the Catechism became increasingly attenuated in later stages of transmission, as seen in Robert Thornton's copy, or in New Haven, Beinecke Library, MS 317. Yet such speculations are needlessly complicated, for they do not change the basic fact that someone - and that person might as well have been Gaytryge - judged the traditional alliterative metre unsuitable to this commission. Though Gaytryge generally honoured the rule against b-verses with long dips both initial and medial, he 
allowed occasional verses with no long dip or with fewer than four positions. These unmetrical types are represented in the first hundred lines of the Catechism by at least $12 \mathrm{~b}$ 'angels and man' [SxxxS], 24b 'of god almighten' [xSxSx], 38b '[fallis] in thaime' [SxxS], 43b 'of iesu crist' [xSxS], and 87b 'god almighty' [SxSx], beside a dozen or more doubtful cases, most of which involve line-final monosyllabic prepositions or pronouns.

Gaytryge's disregard for the traditional metre is paralleled by avoidance of its vocabulary. While the language of the Catechism is formulaic and repetitive, and while this repetition often serves to fill out a half-line unit, the repeated phrases are drawn from the language of religious instruction, not the stock of alliterative formulas. The diction of the Catechism is plain, largely uncolored by rare, archaic, or specifically poetic words. The most notable exceptions perhaps cluster in Gaytryge's treatment of the cardinal virtues and the seven deadly sins. The rare words meth 'moderation' (440), methfulnesse (440), on-lepi 'single' (547), and underlout 'subordinate' (45) belong to the discourse of religious instruction. I cite these words by their headword forms in The Middle English Dictionary, where one finds instructive distributional data. Underlout is recorded mostly in northern texts; meth, methfulnesse, and onlepi evidently had wider geographic distributions but were more common in the thirteenth century than in the fifteenth. On-lepi remained in use longer than the others, in part as a translation of Latin unicum in catechetical works. The words site 'anguish' (471), wand-reth 'misery' (433), and woth 'danger' (425), all of Scandinavian derivation, have attestations that span devotional works and alliterative verse. Meth, too, is recorded in alliterative verse. The verbs forhouen 'to reject, avoid' (449) and hanken 'to snare' (456) are also rare, but only heden 
'to look after, guard' (441) is really an 'alliterative word' - that is, a word attested mostly in alliterative poems.

By its diction, syntax, metre, and general style, the Catechism stands apart from the alliterative tradition. Gaytryge's use of alliterating phrases such as 'to knawe \& to kun' is no challenge to this judgment. Drawing on the work of earlier scholars, J.P. Oakden long ago documented the presence of alliterating doublets and phrases in Robert Mannyng's Handlyng Synne and the works of Chaucer and Gower. ${ }^{44}$ Isolated alliterating phrases in the Catechism do not distinguish this work from Middle English literature in general: in Oakden's assessment, 'many alliterative expressions were the unconscious stock-in-trade of practically all writers'. ${ }^{45}$ Although Gaytryge's Catechism is presented as verse in the earliest and best copies, and though it is closer to alliterative verse than to any other medieval English verse form that we know, its relation to the alliterative tradition is not one of belonging. Rather, Gaytryge seems to have disassembled the form, stripping it of everything that could get in the way of the efficient, unornamented communication that Thoresby had commissioned.

The Catechism may be best understood as a nonce form: an innovation that failed to catch on, attract followers, or even maintain legibility in later stages of its transmission. Late and southern copies represent the text as prose, thus assimilating it to late fourteenth- and fifteenthcentury norms for the provision of religious instruction in English. Had Gaytryge written half a century later, the Catechism might have been prose from the start. In Yorkshire in the middle of the fourteenth century, verse was still the default form for the literature of religious instruction, though the comparable texts - all vastly more ambitious than the Catechism - are written in short four-beat lines with end-rhyme and approximately alternating rhythm. This irregular and 
category-defying text may warrant an expanded frame of reference, including consideration of stylistic models in languages other than English. Hence Lawton's suggestion that Gaytryge was influenced by the system of Latin prose rhythm known as cursus.

\section{Cursus in England, or: Gaytryge's Writing Desk}

By 'cursus' one names the system of accentual cadences developed for medieval Latin prose, associated especially with legal, epistolary, and curial documents, and employed as well in some historiographical and literary works between the twelfth century and the fifteenth. ${ }^{46}$ Ars dictaminis, the rhetorical sub-discipline that taught cursus, arrived in England late and never became so prominent there as it had been in the thirteenth century in northern Italy and in France. Yet French and Italian textbooks of ars dictaminis circulated in England during the fourteenth century; by the end of that century English teachers, evidently centered in Oxford, were producing their own textbooks. ${ }^{47}$ More important than this teaching is evidence of practice, that is, of the use of cursus in Latin documents produced in England. In a foundational study, Noël Denholm-Young observed that, 'in the fourteenth century it seems to have been acknowledged that, if it could be done without elaborating the sentence, even letters patent or close and charters should close the period with a Velox ending, ${ }^{48}$ that is, the stress pattern Sxx $\mid \mathrm{xxSx}$ (here and below, '|' indicates a word boundary), as in facílius comprehéndi. DenholmYoung's assessment was confirmed and amplified by Charles Everitt in a survey of the epistolary correspondence produced in a range of fourteenth- and fifteenth-century English institutions: royal, civic, and episcopal chanceries, monasteries, universities, and lay households ${ }^{49}$ It seems that there was a modest teaching tradition in England by the late fourteenth century, and a more extensive practice of cursus in legal, epistolary, and administrative documents. Writers of 
English texts in the fourteenth and fifteenth centuries could certainly have known the cursus; some probably employed it in their Latin writing. The rhythmical style was probably often learned by example.

This historical characterization may be exemplified in the 1357 Latin memorandum translated by Gaytryge, for stretches of Thoresby's text conform to the rhythmical Latin style taught by ars dictaminis. The seventh article of the faith, quoted above in discussion of Gaytryge's translation technique, may now illustrate the presence and function of cursus in his source text:

[1] Septimus est credere carnis resurrectionem et vítam etérnam, videlicet, quod [2a] omnes in die iudicii sumus in carne et anima veráciter surrectúri, [2b] et tunc erit eterna glória electórum et dampnacio perpétua reprobórum.

This sentence divides into two parts, consisting in [1] formulas of belief, followed after videlicet by [2a, b] a concise exposition of them. Part one rehearses the two final elements of the Apostles' Creed, the second of which yields the rhythmical pattern of cursus planus (Sx|xSx) at clause-end. Two explanatory cola follow, one for each of the quoted phrases of the Creed. The second of these divides further into two commata, stating the starkly binary doctrine of the Last Judgment. The author has constructed the exposition such that each of its syntactic divisions concludes in a cursus velox.

This segment is not representative of the rhythmical style of Thoresby's text throughout its length, but the text is certainly rhythmical. Among clauses punctuated by the EETS editors with a semicolon or period, nearly half (55 of 113) terminate in a single cadence, the cursus 
velox: velox-type endings outnumber the non-canonical cadence $\mathrm{Sx} \mid \mathrm{xxSx}$ (e.g., univérsi

Christiáni) by a ratio of almost $4: 1 .^{50}$ These global figures are all the more impressive, since long stretches of the document - namely, the sections on the ten commandments, seven sacraments, seven works of mercy, and seven deadly sins - are often notably unrhythmical. The author's rhythmical designs are most emphatic in the prologue and conclusion, where Thomas de Aldefeld's punctuation provides better guidance than that of Simmons and Nolloth. ${ }^{51}$ Aldefeld punctuated the prologue and conclusion into twenty-two segments, seventeen of which conclude with a cursus velox. ${ }^{52}$ More sophisticated analysis would be possible but is unnecessary to demonstrate my point: Gaytryge's source text supplies an example of the type of rhythmical Latin prose that, in Lawton's hypothesis, may have influenced Gaytryge's English composition. Denholm-Young observed that fourteenth-century legal and administrative prose exhibits a strong preference for cursus velox at the ends of periods; that preference is evident in the document that lay on Gaytryge's desk as he wrote. Simultaneously, stylistic variation between sections of the text indicates that cursus was not so important to Thoresby that he would have the non-rhythmical sections recast and brought into rhythmical conformity: cursus was most important in the opening and closing addresses, where one expects the most deliberate composition. The hypothesis of English cursus is historically plausible and could help to explain why the Catechism diverges from known English forms. Yet the path from suggestion to demonstration is riddled with difficulties.

\section{Cursus in English: the state of the study}

Medieval English and medieval Latin both had a stress accent. This shared prosodic feature could perhaps have been sufficient foundation for English experiments in Latinate rhythm, 
despite profound differences between English and Latin with respect to the syllabic structure of words, the location and prominence of accent, and the construction of clauses. Gaytryge's Catechism is one of several Middle English texts for which scholars have posited the influence of artificial Latinate rhythm. Others are the devotional treatise A Talkyng of pe Loue of God, Geoffrey Chaucer's Melibee, Parson's Tale, and Boece, and Thomas Usk's Testament of Love. ${ }^{53}$ The relevance of cursus to any of these texts cannot be assessed without confronting methodological problems that are general in scope and impinge especially upon the practice of scansion. ${ }^{54}$ Though an indispensable tool for the representation of prosody, scansion is only as good as its presuppositions, and no study that has claimed to find cursus in Middle English has adequately addressed the problems of method and conception attendant to scansion of Middle English prose. I find five general problems.

(1) Pattern. What rhythmical patterns count as 'English cursus'? Of those who have asked this question, some assume that writers of medieval English prose would have attempted to reproduce precisely the same rhythmical patterns in English as in Latin. A composition is accordingly judged cursus-like if and to the extent that scansion of it yields the canonical Latin patterns: planus, tardus, and velox, to which some add the cursus trispondaicus. Other researchers have assumed that medieval writers of cursus-influenced English prose would have developed and employed rhythmical patterns fitted to the peculiar resources of English and thus differentiated from the canonical Latin patterns that had inspired them. In an influential early study, Morris W. Croll observed that 'it is difficult to reproduce the exact Latin forms in English' and that 'exact reproduction of their form will not always produce their effect ${ }^{55}$ Judging that the 'effect of the Latin may ... sometimes be better produced by 
variations of the forms ${ }^{56}$ Croll undertook to deduce, from the prosodic and morphological differences between medieval Latin and sixteenth-century English, a repertoire of English cadences that may be analogous to the canonical Latin cadences. Croll's rational-deductive treatment supplied an important precedent for Margaret Schlauch and Margery Morgan, both of whom invoke linguistic difference to license departures from the canonical Latin patterns. ${ }^{57}$ The logic is good, but it introduces a strong temptation to construe any persistent rhythmical pattern in an English text as a linguistically motivated modification of a Latin pattern. The result is a weakened case for English cursus. It seems that one cannot know in advance what English rhythmical patterns would constitute an imitation of Latin cursus for a particular author or historical community.

(2) Stress assignment. What words or syllables contribute the definitive stressed positions in the cadence? The definitive stresses of the Latin cursus are generally supplied by the primary word stresses of the last two words in the clause; the location of primary word stress is determined in Latin by the 'rule of the penultimate'. These fixities do not hold in Middle English: words adopted from French may have initial or terminal stress, and there is evidence that the stress of native disyllabic compounds (e.g. wisdom) was shiftable in verse.$^{58}$ Moreover, the frequency of monosyllabic words in Middle English means that the rhythm of clauses cannot be treated as a function of word stress alone. Strings of monosyllables acquire prosodic differentiation via phrasal, semantic, and emphatic stress, which must accordingly enter the calculus of scansion. Nor, finally, may scansion of English proceed as if a neutral reading of linguistic givens. Because English stress is underdetermined at the level of the word, prosodic contours are often susceptible to guidance 
from poetic metre. At what point should one allow scansion to be tilted towards an expected pattern? Anyone attempting to scan Middle English must be prepared to address this manifold of problems in the assignment of stress. Closely related to this is the problem of syllable counting.

(3) Syllable counting. Elision, syncopation, vowel contraction, and diaeresis do cause problems in scansion of medieval Latin, but not often, for medieval authors generally employed the ossified syllabism of Classical Latin in composition of literary verse and rhythmical prose. ${ }^{59}$ Elision is generally not operative in the prose of the dictaminists; other deviations from standard word forms were generally avoided. The contrast with Middle English could hardly be sharper: here syllabic variation is rife. Many common grammatical words have full and reduced forms (neuer and ner, for instance). ${ }^{60}$ Many lexical words were available to poets in doublet-forms, differentiated by syncopation of weak medial syllables or by the retention or loss of weak final $-e$. Scribal spellings are generally not a reliable guide to syllabism in verse and have no greater claim to authority in prose: the spelling hert 'heart' may, for example, represent the conservative disyllabic form with organic final $-e$. The author's dialect region, if known, may reduce the range of possible syllabisms, but many doublet forms had wide, overlapping geographical distributions. Poets found doublet forms useful and evidently cultivated them in literary registers; authors of rhythmic Middle English prose may have done the same. Schlauch acknowledged some doubts, but passed over many others in silence. Lois Smedick's review of the problem remains unanswered in subsequent studies. ${ }^{61}$ 
Problems of template pattern, stress assignment, and syllable count occur as well in scansion of Middle English verse, where, however, they are usually soluble. Poetic metre directs competent readers of verse to select, at the speed of performance, among the array of possible speech forms fuzzily encoded by a given graphic form. Metre may cue résoun or resóun, neuer or its reduced by-form ner. Yet the invisible hand of metrical expectation only begins to work once one knows to expect a metre, and which one to expect. It is doubtful whether prose style projected an abstract pattern strong enough to direct readers between alternative syllabic shapes.

The next two problems are unique to scansion of prose.

(4) Segmentation. At what locations within the text does one expect to find rhythmical patterning? For verse the question generally does not arise. (Middle English alliterative verse is in part an exception.) For curial Latin prose, the question is addressed by the medieval treatises, some of which helpfully teach cursus in conjunction with the structure of the prose sentence and the marks of punctuation appropriate to its constituent parts. ${ }^{62}$ Treatises may prescribe differentiated rhythms for the ends of interior and final clauses; some treatises prescribe rhythms for clause openings, too. Scholars searching for cursus in English prose might reasonably restrict their attention to the ends of major clauses, but which clauses are major, and how are they to be defined? Smedick followed the guidance of scribal punctuation in her study of The Talkyng of pe Loue of God. Schlauch began her study of Chaucer's prose by examining the ends of sentences, presumably as punctuated by editors, but found cursus in interior clauses as well, and at sentence openings. Croll recognized the problem: 'the chief danger that besets the student of cadence is the temptation to discover a proper place for cadence wherever he discovers the forms. ${ }^{96}$ 
(5) Threshold significance and measures of preference. Students of Latin prose do not expect every eligible clause in a rhythmical text to close with one of the canonical patterns; nor would they consider a string of cursus planus endings to qualify a text as deliberately rhythmical. Mathieu Nicolau estimated that 50 per cent or more of Latin clause endings may conform to cursus patterns as a matter of course, without any intention to produce them. ${ }^{64}$ The patterns of accentual rhythm that came to be established as canonical in medieval Latin curial prose are an amplification of rhythmical tendencies inherent in the Latin language, and thus students of Latin prose rhythm must be prepared to measure the observed frequency of, say, cursus planus against some estimate of the incidence of that pattern that would result in the absence of any rhythmical intention. Tore Janson's statistical test of threshold significance probably remains the best available. ${ }^{65}$ Research on English alliterative metre has advanced by attending to absent patterns - that is, constructions that might be expected in the language, but do not appear. ${ }^{66}$ Studies that have claimed to find cursus in English texts have so far failed to recognize the problem.

I doubt whether these five problems of method and conceptualization can be answered; their cumulative effect may be to render the scansion of Middle English prose an impossible project. Lexis, syntax, and word order supply firmer evidentiary basis for characterizing prose style, though probably not a more promising basis for demonstrating influence of cursus. Reviewing the scholarship on Chaucer's prose in 1984, Traugott Lawler considered 'general reference to “controlled rhythm" or "characteristic English rhythm" wiser than Schlauch's too-specific theory of cursus ${ }^{\prime} \cdot{ }^{67}$ The considerations reviewed here support that judgment. 
Even where a vernacular text describes itself as cursus-like, as may be the case in the Vernon copy of A Talkyng of pe Loue of God, the implications of that claim are far from clear, and must be adjudicated on grounds other than rhythm. The unique prologue to A Talkyng of pe Loue of God in the Vernon manuscript states that this treatise is written in 'cadence' and punctuated to aid readers in finding its rhythmical form: 'Men schal fynden lihtliche pis tretys in Cadence. After be bigynninge. zif hit beo riht poynted: \& Rymed in sum stude. To beo more louesum. to hem pat hit reden' ${ }^{68}$ As Margery Morgan recognized, the word cadence is peculiar, and finds its closest parallel in Latin rhetorical textbooks, where the word cadencia is well attested as a synonym for cursus $^{69}{ }^{6}$ Like the Vernon prologue, the Latin textbooks associate cadencia with correct punctuation. On this basis, Morgan proposed that A Talkyng of pe Loue of God was an English imitation of cursus. Following Croll, she added that 'we must not expect to find the identical cursus-patterns familiar in Latin texts' ${ }^{70}$ That line of reasoning is justifiable, but worth pursuing only if we have other reason to believe that cursus is a relevant stylistic model. The prologuer's word 'cadence' notwithstanding, the ars dictaminis and its doctrine of cursus find little traction in A Talkyng of pe Loue of God, a text whose style and purpose align instead with earlier English alliterating prose and with the ruminative Latin style cultivated in twelfth-century monastic preaching and prayer. ${ }^{71}$ Smedick's subsequent scansions of A Talkyng of pe Loue of God were offered as a rebuttal to Morgan's essay, but scansions are probably less damaging to the hypothesis of English cursus than is a careful reading of the text, with attention to its generic affinities and its voice. The Lay Folks' Catechism requires these same forms of attention. 


\section{Conclusion}

In an early appraisal of Hoyt Duggan's paradigm-shifting metrical studies, Lawton challenged metrists to expand their field of reference to 'ancillary models' - that is, models of style beyond the alliterative tradition - and to attend to 'voice as well as meter'. ${ }^{72}$ As illustration, Lawton ventured that '[a]lliterative writing is the English mode of (Latinate) prophecy' and that 'Piers Plowman is written from a cultural desire to render into English the style of the Bible'. ${ }^{73}$ These remain promising lines of inquiry. Malcolm Parkes shows that the marks and practices of punctuation employed in Middle English prose and verse, including alliterative verse, were derived from the punctuation of the Psalms and other liturgical texts: these had an early and direct influence on presentation of vernacular literature. ${ }^{74}$ Influence certainly extended beyond scribal markup. The Lay Folks' Catechism possesses neither the psalmodic and prophetic grandeur of Piers Plowman nor the affective glow of A Talkyng of pe Loue of God, yet a unitary or monolingual explanatory model is no more likely to be adequate to the Catechism than to these other works. In the case of the Catechism the relevant Latin analogues should probably be sought at a humbler scale: neither Bernardine meditations, nor Biblical prophecy, nor the fixed rhythms of the cursus, but instead the plain, stately, unmetered clauses of the Latin Creed and the basic Christian prayers. Whereas the Latin formulas of belief and prayer are concise and pregnant, The Lay Folks' Catechism is expansive, as demonstrated at the beginning of this article with reference to Gaytryge's rendering of the seventh point of belief: three Latin verbs become fourteen in the English version. Yet the Catechism shares the firmness and clarity of Latin pastoralia. The contrast between eterna gloria electorum and dampnacio perpetua reproborum is rendered, perhaps via the corresponding clauses of the Athanasian Creed, as a pair of 
conditionals: Gaytryge affirms 'blis that euermare lastes' 'if we wele do' and 'endeles payne' 'if we iuel do'. The vocabulary is that of plainspoken, everyday English. What could be clearer? To hear the words is to understand. Readers will think inevitably of Piers Plowman. In the decade after Gaytryge wrote, Langland coined the term kynde knowyng precisely to query equations between hearing and understanding in the context of religious instruction. The relevant point here is not Langland's persistent and vigorous questioning of pastoral language,${ }^{75}$ but rather the institutional derivation and pedagogical intent of Gaytryge's language. Thoresby's instructions to Gaytryge echo Church legislation. The archbishop directed his translator to strive 'more for a clear meaning than for an ornamented one' and directed clergy to preach the contents of the 1357 memorandum to the people in the vernacular without recherché verbal artistry ('sine exquisita verborum subtilitate ... populo in vulgari'). John Pecham's Lambeth Constitutions of 1281 had said much the same: preaching of pastoralia should be conducted 'in the common language (vulgariter), without any fanciful and subtle compositional art (absque cuiuslibet subtilitatis textura fantastica). ${ }^{, 76}$ In a sermon that deals in detail with the craft of sermon-making, Philip Repingdon (d. 1424) followed Augustine in warning against rhetorical numerus, adding that “"number", as it is here used, includes the proportion of syllables, meters, and rhetorical colors' ${ }^{77}$ Gaytryge's accomplishment was to think analogically: to bring a conventional stylistic mandate to bear on composition of a text that would not only support English preaching and teaching but also circulate in English. By producing a text that is reminiscent of alliterative poetry yet repudiates its traditional vocabulary, syntax, and metrical form, Gaytryge perhaps shows that he considered traditional alliterative poetry to be a high style vulnerable to the same censure as the Latinate rhetorical sophistication that sometimes clouded contemporary preaching. 
${ }^{1}$ Derek Pearsall, Old English and Middle English Poetry (London, 1977), 150.

${ }^{2}$ N. F. Blake, 'Rhythmical Alliteration', Modern Philology, 67/2 (1969), 118-24; Elizabeth Salter, 'Piers Plowman and The Simonie', Archiv für das Studium der neueren Sprachen und Literaturen, 203 (1966), 241-54; Elizabeth Salter, 'Alliterative Modes and Affiliations in the Fourteenth Century', Neuphilologische Mitteilungen, 79 (1978), 25-35; David A. Lawton, 'Gaytryge's Sermon, Dictamen, and Middle English Alliterative Verse', Modern Philology, 76/4 (1979), 329-43; David A. Lawton, 'Middle English Unrhymed Alliterative Poetry and the South English Legendary', English Studies, 61 (1980), 390-96. See also Thorlac Turville-Petre, The Alliterative Revival (Cambridge, 1977), chap.1; and Richard H. Osberg, 'The Alliterative Lyric and Thirteenth-Century Devotional Prose', Journal of English and Germanic Philology, 76/1 (1977), 40-54.

${ }^{3}$ See Hoyt N. Duggan, 'Final - $e$ and the Rhythmic Structure of the B-Verse in Middle English Alliterative Poetry', Modern Philology, 86/2 (1988), 119-45; Thomas Cable, The English Alliterative Tradition (Philadelphia, 1991); Ad Putter, Judith Jefferson and Myra Stokes, Studies in the Metre of Alliterative Verse, Medium ævum Monographs, new series 25 (Oxford, 2007); and the studies in the next note. David A. Lawton, 'The Idea of Alliterative Poetry: Alliterative Meter and Piers Plowman', in 'Suche Werkis to Werche': Essays on 'Piers Plowman' in Honor of David C. Fowler, ed. by Míceál F. Vaughan (East Lansing, MI, 1993), 147-68, is an early apprehension that the metrists were leaving important questions by the wayside.

${ }^{4}$ Geoffrey Russom, 'The Evolution of Middle English Alliterative Meter', in Studies in the History of the English Language II: Unfolding Conversations, ed. by Anne Curzan and Kimberly Emmons (Berlin, 2004), 279-304; Nicolay Yakovlev, 'The Development of the Alliterative 
Metre from Old to Middle English’ (unpublished D.Phil. thesis, Oxford University, 2008); Eric Weiskott, English Alliterative Verse: Poetic Tradition and Literary History (Cambridge, 2016); Geoffrey Russom, The Evolution of Verse Structure in Old and Middle English Poetry: From the Earliest Alliterative Poems to Iambic Pentameter (Cambridge, 2017); and Ian Cornelius, Reconstructing Alliterative Verse: The Pursuit of a Medieval Meter (Cambridge, 2017).

${ }^{5}$ Salter, 'Alliterative Modes and Affiliations', 32; discussion of the Catechism at 29-33.

${ }^{6}$ Lawton, 'Gaytryge’s Sermon', 342.

${ }^{7}$ The principal edition is Thomas Frederick Simmons and Henry Edward Nolloth, eds., The Lay Folks' Catechism, or, the English and Latin Versions of Archbishop Thoresby's Instruction for the People: Together with a Wycliffite Adaptation of the Same and Corresponding Canons of the Council of Lambeth, EETS, o.s. 118 (London, 1901). The principal studies are Anne Hudson, 'A New Look at the Lay Folks' Catechism', Viator, 16 (1985), 243-58; Anne Hudson, 'The Lay Folks' Catechism: A Postscript', Viator, 19 (1988), 307-9; and Sue Powell, 'The Transmission and Circulation of the Lay Folks' Catechism', in Late-Medieval Religious Texts and Their Transmission: Essays in Honour of A.I. Doyle, ed. by A. J. Minnis (Woodbridge, 1994), 67-84.

${ }^{8}$ On these teaching initiatives see Siegfried Wenzel, Latin Sermon Collections from Later Medieval England: Orthodox Preaching in the Age of Wyclif (Cambridge, 2005), 229-33, 34653.

${ }^{9}$ A. I. Doyle, 'The Manuscripts', in Middle English Alliterative Poetry and Its Literary Background: Seven Essays, ed. by David A. Lawton (Cambridge, 1982), 88-100, 142-47, at 142, n. 6. The register is now York, Borthwick Institute, MS. Abp Reg 11, with the Catechism and accompanying Latin text at ff. $295^{\mathrm{r}}-98^{\mathrm{v}}$. 
${ }^{10}$ Simmons and Nolloth, The Lay Folks' Catechism, xvii.

${ }^{11}$ I quote from the Borthwick Institute's on-line facsimile, ff. $298^{\mathrm{r}}$ and $295^{\mathrm{v}}$, corresponding to 11. 106-17 of the English text in Simmons and Nolloth, The Lay Folks' Catechism. Latin abbreviations are expanded silently; English abbreviations are expanded in italics. Punctuation of the Latin text is editorial. I omit punctuation in the English text but lineate as directed by the scribe's line-ending pointing and line-initial capitals.

12 Traugott Lawler, 'William Langland', in The Oxford History of Literary Translation in English. Vol. 1: To 1550, ed. by Roger Ellis (Oxford, 2008), 149-59, at 154-6.

${ }^{13}$ Lawton, 'Gaytryge's Sermon', 331.

14 This is London, British Library, MS Cotton Galba E.x. The commissioning letter is at ff. $73^{\mathrm{v}}-$ 74r. See R. N. Swanson, 'The Origins of the Lay Folks' Catechism', Medium AEvum, 60/1 (1991), $92-100$.

${ }^{15}$ Swanson, 'The Origins of the Lay Folks' Catechism', 99, 100; I adjust Swanson's translations.

${ }^{16}$ See the conspectus of ascriptions at Hudson, 'New Look', 245-47.

${ }^{17}$ Swanson, 'The Origins of the Lay Folks' Catechism', 99, 100.

${ }^{18}$ I owe this count to Pamela Greig, who is completing a D.Phil. thesis on Gaytryge's text at the University of Nottingham. Until Greig's study appears, the fundamental treatment is Hudson, 'New Look', 245-49, supplemented by Hudson, 'Postscript', 307-9, the witness lists in DIMEV (no. 671), and Powell, 'Transmission and Circulation', 73, n. 24. I follow Hudson's report of manuscript groups and I thank the Borthwick Institute, the Bodleian Library, and the library of Trinity College Cambridge for access to digital facsimiles of manuscripts in their collections. 
${ }^{19}$ George G. Perry, ed., Religious Pieces in Prose and Verse: Edited from Robert Thornton's MS. (Cir. 1440.) in the Lincoln Cathedral Library, EETS, 26 (London, 1867).

${ }^{20}$ Simmons and Nolloth, The Lay Folks' Catechism.

${ }^{21}$ On the Lambeth copy see Hudson, 'New Look', 249-57. On the Thornton copy see Lawton, 'Gaytryge's Sermon', 337-39.

${ }^{22}$ Doyle, 'Manuscripts', 142, n. 6.

${ }^{23}$ Hudson, 'New Look', 248-49.

${ }^{24}$ Hudson, 'New Look', 247. On this manuscript see Anne Hudson and Pamela Gradon, eds., English Wycliffite Sermons, Oxford English Texts, 5 vols (Oxford, 1983-1996), vol. i, 87-88; Anne Hudson, 'The Expurgation of a Lollard Sermon-Cycle', The Journal of Theological Studies, 22/2 (1971), 451-65; and Anne Hudson, 'Observations on a Northener's Vocabulary', in Five Hundred Years of Words and Sounds: A Festschrift for Eric Dobson, ed. by E. G. Stanley and Douglas Gray (Woodbridge, 1983), 74-83. Beatrice Daw Brown, 'Religious Lyrics in MS. Don. C. 13', Bodleian Quarterly Record, 7/73 (1935), 1-7, prints several of the short poems that follow the Catechism in this manuscript.

${ }^{25}$ Hudson, 'New Look', 249.

${ }^{26}$ Lawton, 'Gaytryge's Sermon', 334, n. 11; 336-7; and 340. The EETS edition also commits numerous errors and inconsistencies in report of scribal spellings. These are not vital to my purposes.

${ }^{27}$ See MED 'on-lepi, adj.' and OED 'onlepy, adj.' Forms in ayn- should not be expected in the list of variant spellings in the Middle English Dictionary, for these would be normalized to ain-: 
see Robert E. Lewis, Middle English Dictionary: Plan and Bibliography, 2nd edn (Ann Arbor, 2007), 10, 12.

${ }^{28}$ See note 18 above.

${ }^{29}$ Vincent Gillespie, 'Vernacular Books of Religion', in Book Production and Publishing in Britain, 1375-1475, ed. by Jeremy Griffiths and Derek Pearsall (Cambridge, 1989), 317-44, at 317.

${ }^{30}$ See Hudson, 'New Look', 248, n. 27; Powell, 'Transmission and Circulation', 72-73, n. 22 and 74, n. 28. Powell reports that the extracts and reworkings are all written in prose format. ${ }^{31}$ See the plates in Charlotte D'Evelyn and Anna Jean Mill, eds., The South English Legendary: Edited from Corpus Christi College, Cambridge, MS. 145 and British Museum MS. Harley 2277, with Variants from Bodley MS. Ashmole 43 and British Museum MS. Cotton Julius D. IX, EETS, no. 235-236, 244, 3 vols (London, 1956-1969).

${ }^{32}$ By comparison, the scribe of Piers Plowman in Oxford, Bodleian Library, MS Laud 851 omitted punctuation about 5 per cent of the time: see John Burrow and Thorlac Turville-Petre, eds., The Piers Plowman Electronic Archive, Vol. 9: The B-Version Archetype, SEENET Series a, 12 (2014) <http://piers.chass.ncsu.edu/texts/Bx>, Introduction, section V.2.3.

${ }^{33}$ Quoted in Perry, Religious Pieces in Prose and Verse, vi. Emphasis in original.

34 The passage corresponds to and is substantively identical with 11. 151-56 of the printed edition of the York register text.

${ }^{35}$ In Perry's edition the stress is placed on the final syllable. I assume this was a printing error. ${ }^{36}$ Quoted in Perry, Religious Pieces in Prose and Verse, vi. Emphasis in original. 
${ }^{37}$ W. W. Skeat, 'An Essay on Alliterative Poetry', in Bishop Percy's Folio Manuscript: Ballads and Romances, ed. by John W. Hales and Frederick James Furnivall, 3 vol. (London, 1868), III, xi-xxxix, at xxxvii-viii.

${ }^{38}$ Skeat, 'Essay on Alliterative Poetry', xxxvii, xxxviii. Emphasis in original.

${ }^{39}$ W. W. Skeat, 'Note on the Rhythm of De Octo Vitiis', in Old English Homilies and Homiletic Treatises ... of the Twelfth and Thirteenth Centuries, ed. by Richard Morris, EETS 34 (London, 1868), I, 329-30.

${ }^{40}$ Carleton Brown and Rossell Hope Robbins, eds., The Index of Middle English Verse (New York, 1943); Julia Boffey and A. S. G Edwards, eds., A New Index of Middle English Verse (London, 2005); Linne R. Mooney, Daniel W. Mosser and Elizabeth Solopova, eds., 'The DIMEV: An Open-Access, Digital Edition of the Index of Middle English Verse' <http://www.dimev.net/> [accessed 11 June 2018]; and Kari Anne Rand, The Index of Middle English Prose: Index to Volumes I-XX (Woodbridge, 2014). See too Robert E. Lewis, N. F. Blake and A. S. G. Edwards, Index of Printed Middle English Prose (New York, 1985), items 70 and 71 .

${ }^{41}$ Salter, 'Alliterative Modes and Affiliations', 29, 30.

${ }^{42}$ Lawton, ‘Gaytryge's Sermon', 342.

${ }^{43}$ There is an exception: it seems that a monosyllabic pronoun was acceptable to some poets after a monosyllabic preposition bearing the final lift, as in Sir Gawain and the Green Knight 359b, 'foldes hit to me'. See Putter, Jefferson and Stokes, Studies in the Metre of Alliterative Verse, 34-5. Such lines remain anomalous, as emphasized by Nicolay Yakovlev, 'Prosodic Restrictions on the Short Dip in Late Middle English Alliterative Verse', Yearbook of Langland 
Studies, 23 (2009), 217-42, at 227. The constructions in the Lay Folks' Catechism are not covered by this narrow metrical license. I quote Sir Gawain and the Green Knight from Ad Putter and Myra Stokes, eds., The Works of the Gawain Poet: Pearl, Cleanness, Patience, Sir Gawain and the Green Knight (New York, 2014).

${ }^{44}$ J. P. Oakden, Alliterative Poetry in Middle English, 2 vols (Manchester, UK, 1930-1935), vol. ii, 364-79. On alliteration in alliterative verse, with special attention to consonant clusters, see Donka Minkova, Alliteration and Sound Change in Early English (Cambridge, 2003).

${ }^{45}$ Oakden, Alliterative Poetry, ii, 364.

${ }^{46}$ A concise and accurate explanation of cursus, with extensive bibliography, is provided by Terence O. Tunberg, 'Prose Styles and Cursus', in Medieval Latin: An Introduction and Bibliographical Guide, ed. by F. A. C. Mantello and A. G. Rigg (Washington, D.C., 1996), 11121. I supply further references in later notes.

${ }^{47}$ On the English teaching tradition see Martin Camargo, Medieval Rhetorics of Prose Composition: Five English 'Artes Dictandi' and Their Tradition (Binghamton, NY, 1995), 1-34. The circulation of continental textbooks in England is illustrated by manuscripts of Guido Faba's Summa dictaminis: see N. Denholm-Young, 'The Cursus in England', in Collected Papers on Mediaeval Subjects (Oxford, 1946), 26-55, at 48-50; and Camargo, Medieval Rhetorics of Prose Composition, 16-17.

${ }^{48}$ Denholm-Young, 'The Cursus in England', 40.

${ }^{49}$ Charles Everitt, 'Eloquence as Profession and Art: The Use of the Ars Dictaminis in the Letters of Gilbert Stone and His Contemporaries, $c 1300-c 1450$ ' (unpublished Ph.D. thesis, Oxford University, 1985). Recent studies of cursus in Anglo-Latin include David R. Carlson, 
'Letters of Richard II (1397-8) in the Authorship of William Ferriby', Historical Research, 87/237 (2014), 574-80; and Steven Justice, Adam Usk's Secret (Philadelphia, 2015), 113-31. ${ }^{50}$ This is Michael Winterbottom's 'velox test': see Michael Winterbottom, 'Review: Prose Rhythm in Medieval Latin from the 9th to the 13th Century, by Tore Janson', Medium Avum, 45/3 (1976), 298-300, at 300. Omitted from prosodic analysis are Thoresby's salutation (11. 1-2 in the EETS edition), one line of verse (1.232), and the dating clause (1.263). My analysis allows for consillabicatio, according to which, e.g., audiant et addiscant and unigenitum esse Deum scan as cursus velox. See Tore Janson, Prose Rhythm in Medieval Latin from the 9th to the 13th Century (Stockholm, 1975), 28-30.

${ }^{51}$ Editorial commas in lines 23 and 243 should follow exquisite: the adverb groups with previous material and forms the clause-ending cadence, as Aldefeld's punctuation shows. I ignore Aldefeld's punctuation of list items in the passages corresponding to 11. 15-17 and 259-60 of the EETS edition: what matters is punctuation of clauses.

${ }^{52}$ The remainder include one cursus tardus (haberémus instrúere), two planus (cum súa sequéla, addiscénda compéllant) and two non-canonical rhythms (obseruántiis instrúcti, in áliquo praejudicáre).

${ }^{53}$ See Margery M. Morgan, 'A Treatise in Cadence', Modern Language Review, 47/2 (1952), 156-64; Margaret Schlauch, 'Chaucer's Prose Rhythms', PMLA, 65/4 (1950), 568-89; Margaret Schlauch, 'The Art of Chaucer's Prose', in Chaucer and Chaucerians: Critical Studies in Middle English Literature, ed. by Derek Brewer (University, AL, 1966), 140-63, at 155-162; and Eleanor Johnson, Practicing Literary Theory in the Middle Ages: Ethics and the Mixed Form in Chaucer, Gower, Usk, and Hoccleve (Chicago, 2013), 61-78. 
${ }^{54}$ My predecessor in this is Lois K. Smedick, 'Cursus in Middle English: A Talkyng of pe Loue of God Reconsidered', Mediaeval Studies, 37 (1975), 387-406.

${ }^{55}$ Morris W. Croll, 'The Cadence of English Oratorical Prose', Studies in Philology, 16/1 (1919), $1-55$, at 15. Emphasis in original.

${ }^{56}$ Croll, 'The Cadence of English Oratorical Prose', 15.

${ }^{57}$ Schlauch, 'Chaucer's Prose Rhythms', 575-7, 580-1; Morgan, 'A Treatise in Cadence', 163.

${ }^{58}$ See Donka Minkova, 'Nonprimary Stress in Early Middle English Accentual-Syllabic Verse’, in English Historical Metrics, ed. by C. B. McCully and J. J. Anderson (Cambridge, 1996), 95119 , at 107 , reasoning that a 'salient secondary stress' may be elevated to 'metrical ictus' in the Ormulum.

${ }^{59}$ Dag Norberg, An Introduction to the Study of Medieval Latin Versification, ed. by Jan Ziolkowski, trans. by Grant C. Roti and Jacqueline de La Chapelle Skubly (Washington, D. C., 2004), 23-30, details typical classes of syllabic deformation in medieval Latin verse.

${ }^{60}$ Russom, The Evolution of Verse Structure, 141-2, is a good summary discussion.

${ }^{61}$ See Smedick, 'Cursus in Middle English', 390-1.

${ }^{62}$ An influential example is Guido Faba's Summa dictaminis, sections LXXX-LXXXIII and LXXXVIII-LXXXIX, printed in Augusto Gaudenzi, ed., 'Guidonis Fabe Summa Dictaminis', Il Propugnatore, n.s. 3 (1890), i, 287-338; ii, 345-93. A concise synthetic treatment is found in the Libellus de arte dictani rhetorice attributed to Peter of Blois, printed at Camargo, Medieval Rhetorics of Prose Composition, 46-7.

${ }^{63}$ Croll, 'The Cadence of English Oratorical Prose', 21; cf. 4-5. 
${ }^{64}$ Mathieu G. Nicolau, L'origine du 'cursus' rythmique et les débuts de l'accent d'intensité en latin (Paris, 1930), 126-30. This estimate is based on scansion of Latin prose from the classical period, thus prior to the development of specifically accentual systems of prose rhythm. ${ }^{65}$ Janson, Prose Rhythm in Medieval Latin, 19-28. See Tunberg, 'Prose Styles and Cursus', 119-20; and Giovanni Orlandi, 'Metrical and Rhythmical Clausulae in Medieval Latin Prose: Some Aspects and Problems', Proceedings of the British Academy, 129 (2005), 395-412. ${ }^{66} \mathrm{An}$ example is the rarity of lexical monosyllables in terminal position in the Middle English alliterative line. See Stephen A. Barney, 'Langland's Prosody: The State of the Study', in The Endless Knot: Essays on Old and Middle English in Honor of Marie Borroff, ed. by M. Teresa Tavormina and R. F. Yeager (Woodbridge, 1995), 65-85, at 82-5.

${ }^{67}$ Traugott Lawler, 'Chaucer', in Middle English Prose: A Critical Guide to Major Authors and Genres, ed. by A. S. G. Edwards (New Brunswick, N.J, 1984), 291-313, at 293. The inset quotations are from Ralph W. V. Elliott, Chaucer's English (London, 1974).

${ }^{68}$ I quote from Wendy Scase, ed., A Facsimile Edition of the Vernon Manuscript: Oxford, Bodleian Library, MS. Eng. Poet. A. 1, Bodleian Digital Texts, 3 (Oxford, 2011), but employ a colon for the scribe's punctus elevatus.

${ }^{69}$ Morgan, 'A Treatise in Cadence', 157-58. The word cadence occurs once in Chaucer's surviving works and had a vogue among the fifteenth-century Chaucerians, as a name for or attribute of artificial literary style. The Vernon prologue is possibly the earliest of the surviving English attestations; it is in any case independent of the others. The form of the word may suggest borrowing through French, but historical dictionaries of French first record cadence late in the following century. The Dictionary of Medieval Latin from Brisish Sources cites only John 
of Garland's Parisiana Poetria for the sense 'cadence, rhythm' (s.v. 'cadentia', sense c), but see Camargo, Medieval Rhetorics of Prose Composition, 46 (1. 62), 97 (11. 151-6), 103, and 223.

${ }^{70}$ Morgan, 'A Treatise in Cadence', 163.

${ }^{71}$ See discussions of this ornate devotional style in Cecily Clark, 'As Seint Austin Seith ...', Medium Avum, 46/2 (1977), 212-18; Elizabeth Salter, English and International: Studies in Literature, Art and Patronage of Medieval England, ed. by Derek Pearsall and Nicolette Zeeman (Cambridge, 1988), 70-74; Christine Mohrmann, Études sur le latin des chrétiens. Vol. II: Latin chrétien et médiéval (Rome, 1961), 351-67; and Karl Polheim, Die lateinische Reimprosa (Berlin, 1925), 389-90.

${ }^{72}$ Lawton, 'The Idea of Alliterative Poetry', 163, 168.

${ }^{73}$ Lawton, 'The Idea of Alliterative Poetry', 168.

${ }^{74}$ M. B. Parkes, Pause and Effect: An Introduction to the History of Punctuation in the West (Berkeley, 1992), 76-9 and 104-5; and compare Parkes's negative assessment of the influence of dictaminal systems of punctuation, at p. 46.

${ }^{75}$ Salient references are Anne Middleton, 'Dowel, the Proverbial, and the Vernacular: Some Versions of Pastoralia', in Medieval Poetics and Social Practice: Responding to the Work of Penn R. Szittya, ed. by Seeta Chaganti (New York, 2012), 143-69; and Ralph Hanna, 'Speculum Vitae and the Form of Piers Plowman', in Answerable Style: The Idea of the Literary in Medieval England, ed. by Frank Grady and Andrew Galloway (Columbus, 2013), 121-39.

${ }^{76}$ Text and translation from Wenzel, Latin Sermon Collections from Later Medieval England, 232. 
77 'Ad numerum prout hic sumitur intelligas pertinere proporcionem sillabarum, metrorum, et colores rhetoricos'. Text and translation from Wenzel, Latin Sermon Collections from Later Medieval England, 342. Additional examples of this type of counsel are collected at Traugott Lawler, The Penn Commentary on Piers Plowman, Vol. 4: C Passūs 15-19; B Passūs 13-17 (Philadelphia, 2018), 161-2, with reference to the Lay Folks' Catechism. 